\title{
Kwang-Yeong Shin* \\ Neo-Liberal Economic Reform, Social Change, and Inequality in the Post-Crisis Period in South Korea
}

https://doi.org/10.1515/asia-2018-0038

\begin{abstract}
This paper attempts to explore the dynamics of inequality in the postfinancial crisis period, which has been reshaping the lifeworld in South Korea. The neo-liberal economic reform in the post-crisis period has drastically affected income distribution, generating working poor and large marginalized social groups. The sharp rise of income inequality has been conducive to an unprecedented social crisis associated with the lowest birth rate and the highest poverty rate of the elderly in the world. Under the poor South Korean welfare system, the increase in precarious employment and rising inequality and poverty have undermined the social fabric, generating a drastic increase in suicide, family dissolution, and social distrust.
\end{abstract}

Keywords: Neo-liberalism, inequality, poverty, social crisis, South Korea

\section{Introduction}

The rise in income inequality became a political issue with the explosion of discourse on 'social polarization' in the 2000s in South Korea. Economic concentration has been a political concern as a bi-polarization in profit and wage has persisted in the 2000s. Also, the rising relative poverty rate among socially disadvantaged social groups has also contributed to the prevalence of discourses on economic inequality, the labor market, and welfare policies.

This drastic economic transformation heavily influenced rising inequality in South Korea after the financial crisis in 1997 and social changes associated with the economic reform in the post-crisis period such as population change and the family crisis. The crisis management policy carried out by the Korean government, under the guidance of the IMF, has resulted in the mass bankruptcy of companies and a massive discharge of employees. Thus, the financial crisis in 1997, not predicted nor expected, has exerted long-term influences on the work and family life of the whole population in South Korea. Moreover, along with the

*Corresponding author: Kwang-Yeong Shin, Department of Sociology, Chung-Ang University, 84 Heukseok-Dong Dogjak-Gu, Seoul 156-767, Korea. E-mail: kyshin@cau.ac.kr 
economic transformation, the continuous increase in life expectancy has exacerbated income distribution with the sudden increase in the numbers of elderly people struck by poverty. Also, the family crisis, triggered by the financial crisis, has been associated with family dissolution that culminated in the second highest divorce rate in the OECD in 2003. The financial crisis and the subsequent neo-liberal economic reform have exerted a profound impact on social relations at the workplace as well as at home.

While South Korea, one of four newly industrialized countries in East Asia, presented rapid economic growth with an equal distribution of income until the 1980s, it has now become one of the most unequal societies in Asia. As social inequality has been growing, 'social polarization' has become a new buzzword in academics and a big political issue in the last two presidential elections, reshaping economic policies and welfare programs in the 2010s. While the chaebols ${ }^{1}$ still advocated the neo-liberal economic policy, labor unions and civil society organizations demanded a strengthening of welfare programs and social protection for precarious workers.

This paper explores the socio-economic dynamics of the rising social inequality in the post-crisis period in South Korea since 1997. The next section of this paper deals with the macro-structural change in the economy and society after the financial crisis in 1997. The financial crisis in 1997 became a watershed of social transformation in South Korea. It altered not only the employment practice of companies but also the structure of the labor market that developed in the period of rapid economic growth. Secured employment, such as lifetime employment, has been significantly eroded and the number of precarious workers with low wages and no job security has rapidly increased.

The third section of this paper deals with the paradox of aging while the economic restructuring was taking place. South Korea experienced the second population transition in the 1990s. The first population transition occurred in the 1970s when the birth rate decreased rapidly. It was an outcome of the birth control policy implemented by the state. The second population transition began in the 1990s when both the birth rate and mortality rate jointly decreased. This second population transition occurred when the early retirement of old workers was enforced by employers after the financial crisis. It resulted in longer later life without income or low income due to the poor social welfare system for the elderly.

The fourth section of this paper analyses the effects of family change on income distribution per household. In particular, the rise in the divorce rate and

1 Chaebols are large family-owned business conglomerates in South Korea that dominate the economy. For an introduction, see Kim 2010. 
single households contributes to increasing the relative poverty rate with the increase in the low-income groups. Family dissolution due to a weakening of the familial patriarchy in the post-crisis period contributed to the rise of a new poverty of single households. In particular, the rapid growth of the single female household also contributed to an increase in the poverty rate since the relative poverty rate of the single female household was four times higher than that of the non-single household.

The fifth section of the paper reports on the decomposition of income inequality regarding three dimensions of socio-economic change. Analyzing the household finance and welfare panel survey data, we examined the trends and causes of income inequality in South Korea. It shows that rising inequality and expanding income inequality has been an outcome of the interplay between neo-liberal economic reforms, population change, and family change. The most important factor of income inequality is employment status, representing class position.

The concluding section of this paper discusses how the Moon Jae-in government, inaugurated in May 2017, has tried to halt the general trend of rising income inequality by introducing social welfare programs and raising the minimum wage. However, this paper argues that it will take a much longer time with more profound policy reforms to effectively reverse the trend of rising income inequality.

\section{The financial crisis and the rise of precarious work}

A financial crisis occurred in 1997, one year after Korea gained membership of the OECD. Since the Kim Young-sam government (1992-1997) proclaimed that South Korea became a member of the OECD, the unexpected financial crisis in Korea was a shocking to both South Koreans and the world. It revealed the functional schism between the developmental state ${ }^{2}$ and the newly liberalized economy. The chaebols had been responsible for implementing an exportoriented economic state policy with protection and support under the state's economic planning. While the OECD membership did not allow the state to

2 Developmental state is a type of capitalism in East Asia, which is characterized by having strong state intervention, through extensive planning and regulation. For discussions of South Korea as a developmental state, see Amsden 1989; Chibber 2014. 
support private companies anymore, the chaebols maintained their management style, debt financing, and expansion of the market share.

The financial crisis was a liquidity crisis in which a shortage of foreign currency reserves, US-American dollars, ended with the bankruptcy of chaebols and major banks. The primary reasons for the financial crisis were a rapid deregulation of the domestic financial market, government and big corporation collusion, and excessive foreign debt. ${ }^{3}$ Foreign debt quadrupled during the Kim Young-sam government, making the national economy insolvent.

The IMF provided bailout money to the Korean government under the condition that the Korean government implemented extensive economic reform prescribed by the IMF. In a nutshell, the policy principle of the IMF was based on the Washington Consensus, which included cuts in public spending, deregulation of the market, privatization of the public sector, and the opening of the domestic market. $^{4}$

The government played a significant role in restructuring the market again. While the previous government intervened in the market to formulate economic growth, the new democratic government was to work as a visible hand to manage the economic crisis. The neo-liberal economic reforms by the democratic government paved a new way of economic governance as the democratic government worked in collaboration with the IMF and the progressive union confederation at the same time. Although the new economic governance was short-lived, it had a great impact on the economy.

The new economic governance by the Kim Dae-jung government was symbolized by social agreement within the newly established tripartite committee, which was proposed by the president-elect Kim Dae-jung in February 1998. Kim Dae-jung established the tripartite committee that consisted of representatives of labor, capital, and the government to formulate a social pact between labor and capital. It included representatives of the Korea Confederation of Trade Unions (KCTU), an illegal union confederation at that time, and the Federation of Korean Trade Union (FKTU), the legal union confederation sponsored by the authoritarian regime.

The KCTU accepted the discharge of redundant employees and the employment of non-regular workers in exchange for the legalization of the teachers' union. Thus, mass layoffs became possible without the consent of the union. An immediate impact of the social pact was massive layoffs since March 1998. Almost 100,000 workers lost their jobs every month in 1998 resulting in approximately two million unemployed at the end of 1998.

3 Baliño and Ubide 1999.

4 Williamson 1990. 
Private companies also implemented an early retirement scheme for older workers to reduce labor costs; the average retirement age significantly decreased after the financial crisis. Early retirement played a crucial role in aggravating income inequality. Because the average retirement age of the employed was about 53 in the 2000s, ${ }^{5}$ those who retired from their work could not escape the severe loss of income in their later life course. It has been extremely difficult for retiring workers to find new jobs since the employment system has been embedded in a patriarchal system in which age plays an implicit but significant role in the labor market. Thus, the majority of the retired in their 50s and 60s had to launch their own business or work as non-regular workers. Therefore, the high rate of self-employment in Korea did not decline in the post-crisis period. The proportion of the self-employed in Korea was already much higher than those of other countries in the 1990s and tended to decline as other industrial societies did. Those who were working as self-employed comprised $26.04 \%$ of the total labor force in 1991 but it increased up to $27.06 \%$ in 1997; it began to decrease again after 2003. The self-employment rate in Korea is still twice higher than that of Japan and close to that of Chile. ${ }^{6}$

Instead of regular workers, non-regular workers such as limited term workers, dispatched workers, temporary workers, and interns were hired. The non-regular workers increased by almost $8 \%$ from $27 \%$ in 1997 to $35 \%$ in 2003. Non-regular workers were precarious workers on low wages with no job security. Companies encouraged early retirement of the old workers and replaced them with young non-regular workers. Thus, a fragmentation of the labor market and workers took place more extensively than before.

As Figure 1 shows, the proportion of non-regular workers was stagnating in the 2010s. However, the wage gap between regular workers and non-regular workers has widened over the same period. The proportion of non-regular workers decreased from $37.0 \%$ to $32.8 \%$ between 2004 and 2016, but the average wages of non-regular workers fell also from $67.1 \%$ to $53.5 \%$ of the average wages of regular workers between 2002 and 2016. About one-third of employees are precarious workers with low wages, and inadequate social protection. They are confined to the second segment of South Korea's dual labor market.

South Korea experienced two economic crises: one was the economic crisis in 1997 when the financial crisis in Southeast Asia spread to South Korea and another was the economic crisis in 2008, when the subprime mortgage crisis in the USA engulfed the whole globe. The Southeast Asian financial crisis began in

5 Statistics Korea 2015.

6 OECD 2017. 


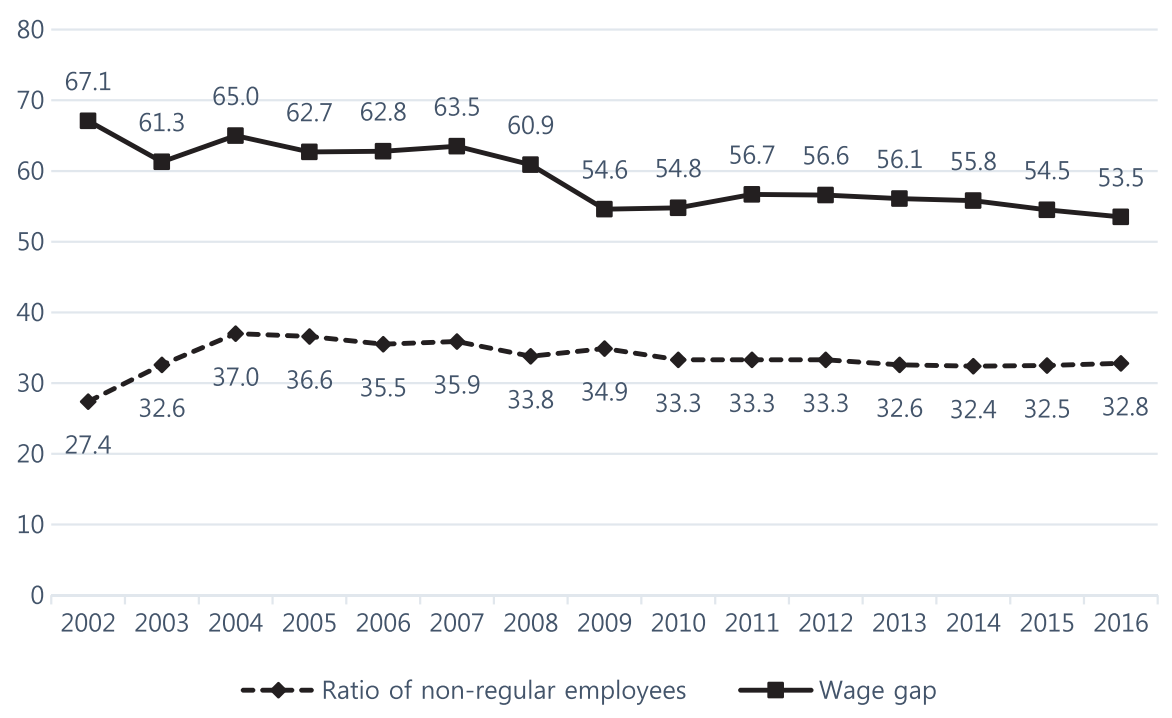

Figure 1: Share of non-regular employment and wage gap in \% (2002-2016).

Source: KLI (2016: 32).

Thailand in 1996 and affected the Korean economy as chaebols began to aggressively invest in foreign countries with their enhanced credit (coming from Korea's new membership of the OECD in December 1996). While globalization affected the Korean financial market, the old institution and its norms in the developmental state persisted. Thus, a "lack of transparency in financial and corporate sectors, weak governance, and poor regulatory systems hampered the efficient functioning of markets in disciplining the Korean economy." ${ }^{7}$

Economic concentration intensified with mergers and acquisitions even after the financial crisis in 1997. The big companies with over 300 employees, made up only $0.1 \%$ of the total companies, employed $14.23 \%$ of the total workforce in 2017. The four major chaebols dominated with $60 \%$ of the total sales in 2015. A small number of business groups had a significant share of the entire economy. The monopoly or oligopoly status of the chaebol strengthened. The 30 largest companies controlled $26.1 \%$ of all sales, $45.5 \%$ of the sales in manufacturing, and $16.1 \%$ of sales in the service sector in $2010 .^{8}$

The rise of non-regular workers has generated a new form of labor market duality. Fragmentation of the labor market with diverse types of non-regular

7 Baliño and Ubide 1999: 7.

8 Lee 2014: 6. 
employment could keep the unemployment rate low; it has generated precarious workers with lower wages, poorer job training, and lower social insurance. That contributed to higher wage inequality and lowered social mobility in the 2000s. ${ }^{9}$

The restructuring of the economy also transformed wage determination in two ways. One was the more significant role of the organization in the determination of individual wages. In particular, the wage level of individual employees has been increasingly influenced by the firm's size. ${ }^{10}$ Those who are working at large companies enjoy higher wages than those who are working at small companies. Thus, those who are working at chaebol firms have enjoyed the highest level of wage among employees. Although the unionized rate of workers is less than $10 \%$, workers in large companies are mostly organized. Thus, the effect of the union on wages has been maintained among workers at large companies so that the wage gap between big companies and small- and medium-sized companies has been widening.

Another was the diminishing effect of an individual's education on their wage. The rate of entering university among high school graduates has continuously increased over the past several decades. Thus, the rate of entering tertiary education in Korea was the highest level in the world in the 2000s, surpassing the USA. ${ }^{11}$ While an advantage of a university diploma over high school graduation still can be maintained, the relative premium of a university diploma has been significantly diminished for the last two decades. Figure 2 displays the trends of wage differentials by the level of completed education. In the 1980s, employees with university degrees received wages 2.316 times larger than that of high school graduates. The wage differentials by education level continuously reduced in the 1990s and 2000s. Although there was the U-shape turn in wage differentials by education level in the 2010s, the wage gaps by education level are not so big as before. The relative earnings advantage of a university degree in South Korea is even lower than the OECD average. ${ }^{12}$

In contrast, the effect of firm size on wage has increased over the last three decades. As Table 1 shows, wage gap by firm size was negligible in the 1980s. The wage gap widened in the 1990s and 2000s. The concentration of economic power to big corporations has generated wage differentiation by firm size. The wage gap by firm size was intensified after the financial crisis in 1997. Paradoxically, the state's reform policies for the economic restructuring after the financial crisis in 1997 accompanied massive mergers and acquisitions of

\footnotetext{
9 Dao et al. 2014.

10 Chung 2002, 2007.

11 OECD 2017: 42.

12 OECD 2017: 114.
} 


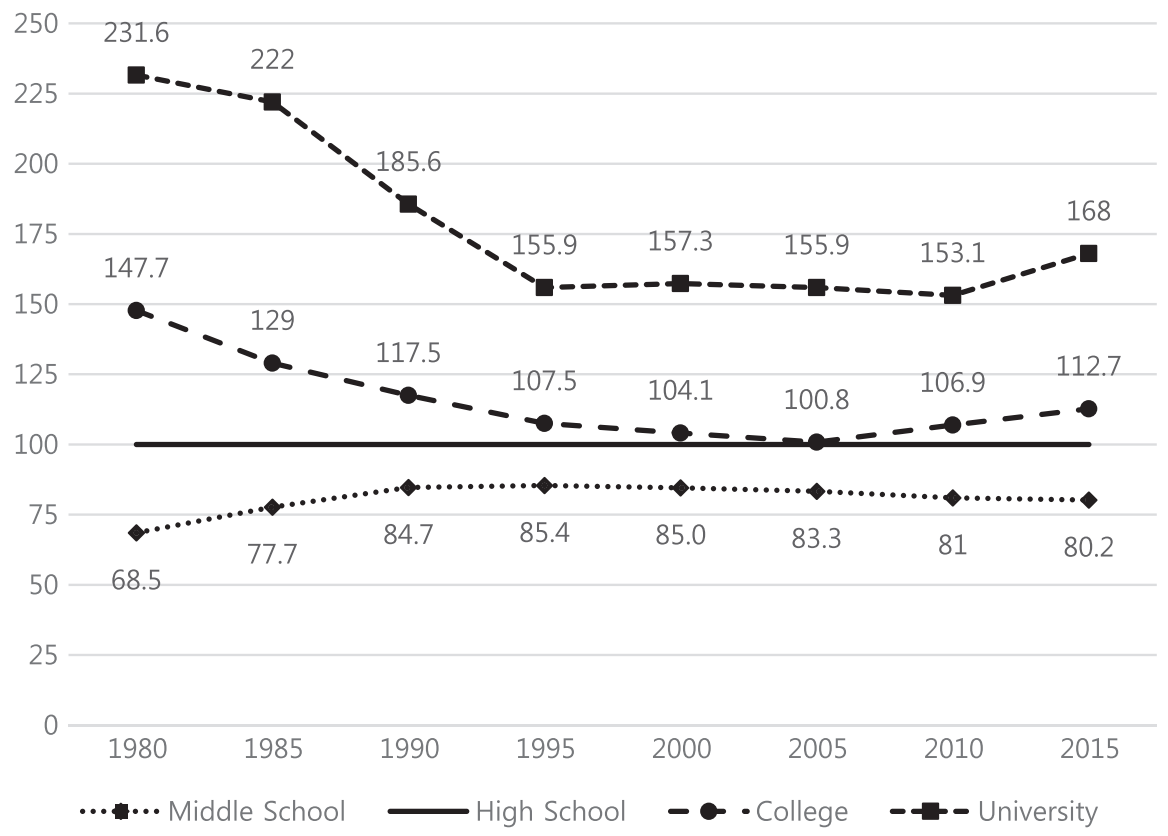

Figure 2: Trends of wage differentials by the level of education in \%, 1980-2015.

Source: KLI (2017).

Table 1: Employees' wages by firm size, 1980-2015.

\begin{tabular}{lrrrrrr}
\hline & $5-9$ & $\mathbf{1 0 - 2 9}$ & $\mathbf{3 0 - 9 9}$ & $\mathbf{1 0 0 - 2 9 9}$ & $\mathbf{3 0 0 - 4 9 9}$ & $\mathbf{5 0 0 +}$ \\
\hline $\mathbf{1 9 8 0}$ & - & 166 & 177 & 173 & 183 & 178 \\
& & $(0.938)$ & $(1.00)$ & $(0.977)$ & $(1.034)$ & $(1.006)$ \\
$\mathbf{1 9 8 5}$ & - & 308 & 314 & 308 & 340 & 344 \\
& & $(0.981)$ & $(1.00)$ & $(0.981)$ & $(1.083)$ & $(1.096)$ \\
1990 & - & 549 & 572 & 603 & 698 & 741 \\
& & $(0.960)$ & $(1.00)$ & $(1.054)$ & $(1.220)$ & $(1.295)$ \\
1995 & - & 1,082 & 1,108 & 1,175 & 1,334 & 1,511 \\
& & $(0.977)$ & $(1.00)$ & $(1.060)$ & $(1.204)$ & $(1.364)$ \\
2000 & 1,274 & 1,497 & 1,567 & 1,713 & 1,973 & 2,195 \\
& $(0.800)$ & $(0.956)$ & $(1.00)$ & $(1.093)$ & $(1.259)$ & $(1.401)$ \\
2005 & 1,783 & 2,081 & 2,259 & 2,517 & 2,822 & 3,541 \\
& $(0.782)$ & $(0.921)$ & $(1.00)$ & $(1.114)$ & $(1.249)$ & $(1.568)$ \\
2010 & 2,212 & 2,561 & 2,837 & 3,126 & 4,291 & - \\
& $(0.763)$ & $(0.903)$ & $(1.00)$ & $(1.102)$ & $(1.513)$ & \\
2015 & 2,539 & 3,063 & 3,351 & 3,487 & 5,017 & - \\
& $(0.761)$ & $(0.914)$ & $(1.00)$ & $(1.041)$ & $(1.497)$ & \\
\hline
\end{tabular}

Source: KLI (2017: 61). 
chaebol companies and led to more severe economic concentration by a smaller number of chaebols. The expanding wage differentials by firm size indicate a rising inequality for employees.

\section{Aging and changing family}

South Korea has experienced significant population changes that were partly associated with economic change as well. One of them was the change in the age structure of the population due to the low birth rate and increased aging. South Korea succeeded in reducing the birth rate with the aid of the United Nations Development Programme (UNDP) in the 1960s and 1970s. ${ }^{13}$ The government implemented an extensive population control policy, pursuing a "two children for one family" policy to reduce the birth rate. It was a part of the state's economic planning manufactured by the Economic Planning Board (EPB) in the era of high economic growth. The goal of the EPB was achieved in the early 1980s when the total fertility rate went below 2.1. While the EPB stuck to lowering the total fertility rate only, it did not expect the negative impact of the falling birth rate on the national economy. South Korea's birth rate fell to the lowest birth rate in the world in the 2010s.

Another demographic transformation was the aging of the population, which was far faster than expected. ${ }^{14}$ While the proportion of people over 65 in South Korea is lower than the OECD average in 2014, it will be the highest in 2050. The average annual growth of the elderly population has been the highest in South Korea among the OECD countries. ${ }^{15}$ South Korea has become a fast aging society with more than $14 \%$ of the population over 65 in 2017.

As Figure 3 shows, the birth rate has been declining from the mid-1980s and the number of those over 65 years of age has been increasing since the late 1990s. The population dynamic was not perceived as a serious problem by policymakers until the 2000s, when it began to significantly affect the economy and income distribution after the financial crisis. As massive layoffs were focused on older employees to reduce labor costs under the seniority wage system, the poverty rate of the elderly was expected to increase gradually in the 2000s.

13 Nam and Ro 1981.

14 OECD 2016.

15 OECD 2016: 19. 


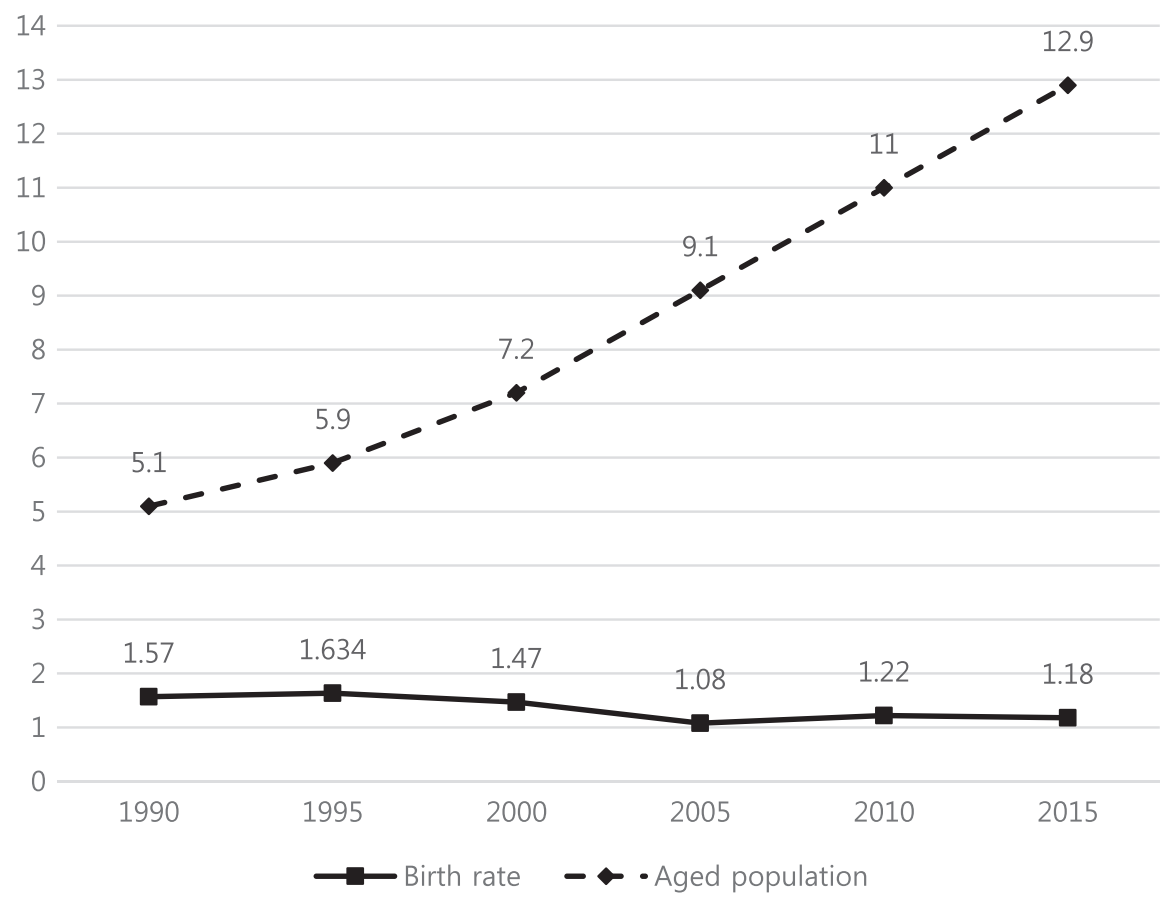

Figure 3: Trends of aging (in \%) and total fertility rate, 1990-2015.

Source: Statistics Korea (2017).

The rapid increase in the elderly population has significantly contributed to the rise of economic inequality. The mass layoff of older workers after the financial crisis in 1997 and the underdevelopment of the welfare system for the elderly led to the rapid growth of the poverty rate among the elderly in the 2000s. While like the USA and Mexico, South Korea has been classified as a country with a high rate of poverty, the elderly poverty rate in South Korea has been far higher than those of the USA and Mexico in the 2000s. The financial crisis had a significant impact on relative poverty. Figure 4 shows the trends of the relative poverty rate for all households and the elderly households. The relative poverty rate based on regular income increased by $3.5 \%$ from $8.7 \%$ to $12.2 \%$ from 1997 to 1999 . While it increased substantially after the financial crisis, the most remarkable increase in the relative poverty rate could be observed among the elderly and the single mother households. The poverty rate of the elderly more than doubled from $24.1 \%$ in 1997 to $53.9 \%$ in 2015. Now almost half the elderly population over 65 years of age suffer from poverty in South Korea in the 2010s. Single mother households also show a significant increase in the relative 


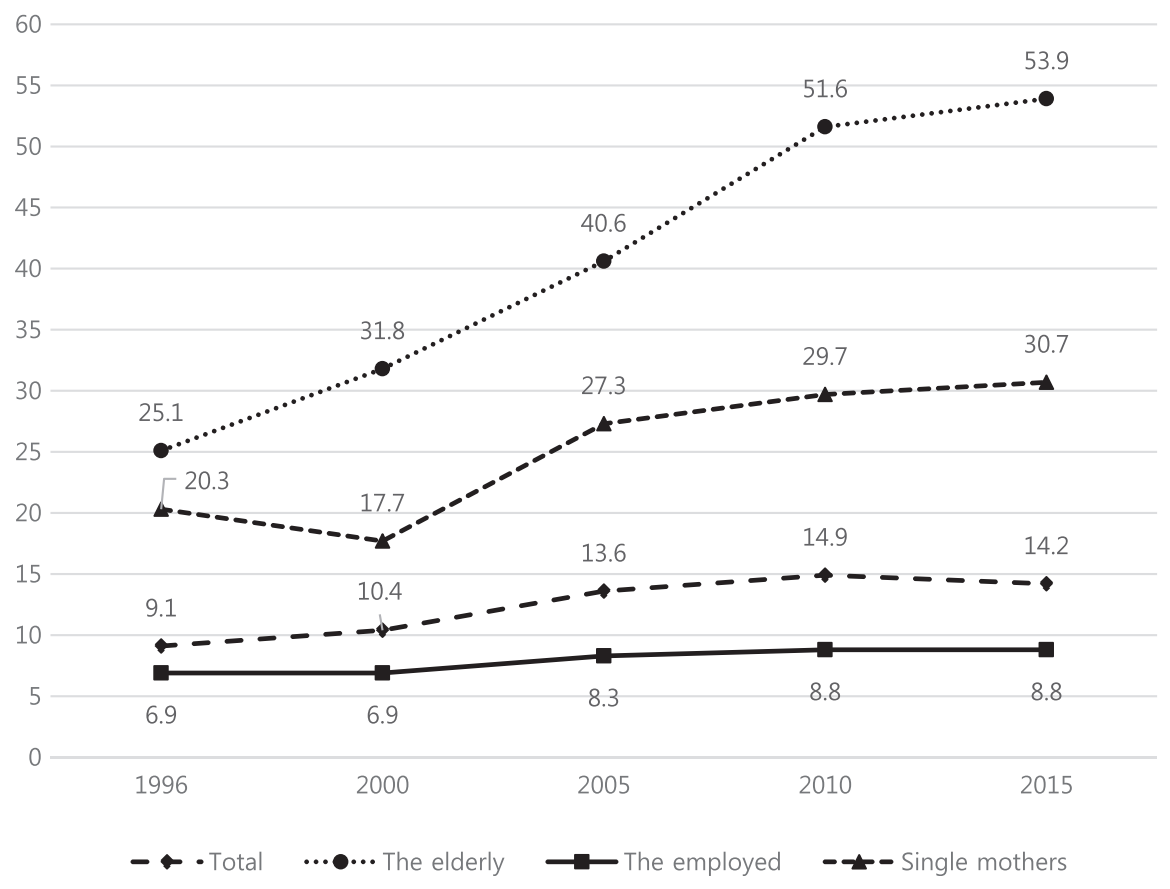

Figure 4: Relative poverty rate in \%, 1996-2015.

Source: KLI (2016: 48, 68, 80 and 106).

poverty rate from $17.7 \%$ in 2000 to $30.7 \%$ in 2015 . Both the elderly and single mother households were most severely affected by the financial crisis.

\section{Transformation of the family}

An impact of the financial crisis could be found in the change in family dynamics. The neo-liberal economic reforms have undermined the basis of the patriarchal family system. The family system in South Korea was characterized by patriarchy, strongly influenced by Confucian ethics, which emphasizes sexual division of labor in the family and society. Confucianism, not as an institutionalized religion but as popular moral and ethical principles, has functioned as a "familial religion". ${ }^{16}$ The primary tenet of Confucianism is a hierarchical relationship between husband and wife and parent and child. The male

16 Kim and Finch 2002; Park and Cho 1995. 
breadwinner model of the family, an institutional form of the gender division of labor based on duties and obligations of husband and wife in Confucian ethics, persists even in the rapidly industrialized society. ${ }^{17}$ While husbands have authority and power within the family, they can be criticized and demoralized if they cannot earn enough income.

The financial crisis significantly weakened the power of the husband based on the husband's economic responsibility for providing living expenses. The unemployed husband failed to play the proper role of guarantors of the family income. It severely undermined the patriarchal authority of the husband within the family, generating severe familial conflicts and occasionally family dissolution, that is, divorce.

The immediate effect of the family crisis was an explosion in the divorce rate and the rise of single-parent households, strongly associated with an increasing poverty rate in the post-crisis period after 1997. The divorce rate doubled between 1997 and 2003. The lagged effect of a husband's unemployment on divorce appeared in the 2000s. In 2003, South Korea showed the highest divorce rate among OECD countries. The crude divorce rate, that is the number of divorces per 1,000 persons of the mean population, was 1.7 in 1996 and 3.4 in 2004, surpassing those of other European countries. ${ }^{18}$

Another dramatic change in the family system is the rapid increase in number of the single household. Single households increased from $12.7 \%$ in 1995 to $27.2 \%$ in $2016 .{ }^{19}$ Traditionally, single households are not considered as a family because it does not include a family relationship. However, the single household becomes a dominant form of life at a particular stage of one's life course in contemporary society. While a spouse's death was the most frequent reason for the single household for people in their 60s and 70s, divorce was the most common reason for the single household in people's $40 \mathrm{~s}$ and $50 \mathrm{~s}^{20}$

The relative poverty rate varies according to the household size. As Figure 5 shows, single households show the highest relative poverty rate, $53.92 \%$, among all households. Two-person households also show a higher relative poverty rate than the average relative poverty rate of the total population. In short, the larger the household, the smaller the relative poverty rate. Thus, the increase of the single household has significantly contributed to the rise of the poor in the 2000s. Other things being equal, the rapid growth in the proportion of single households tends to increase income inequality in South Korea.

\footnotetext{
17 Kim and Finch 2002: 43.

18 OECD 2017.

19 Statistics Korea 2017: 4.

20 Chung et al. 2012: 36.
} 


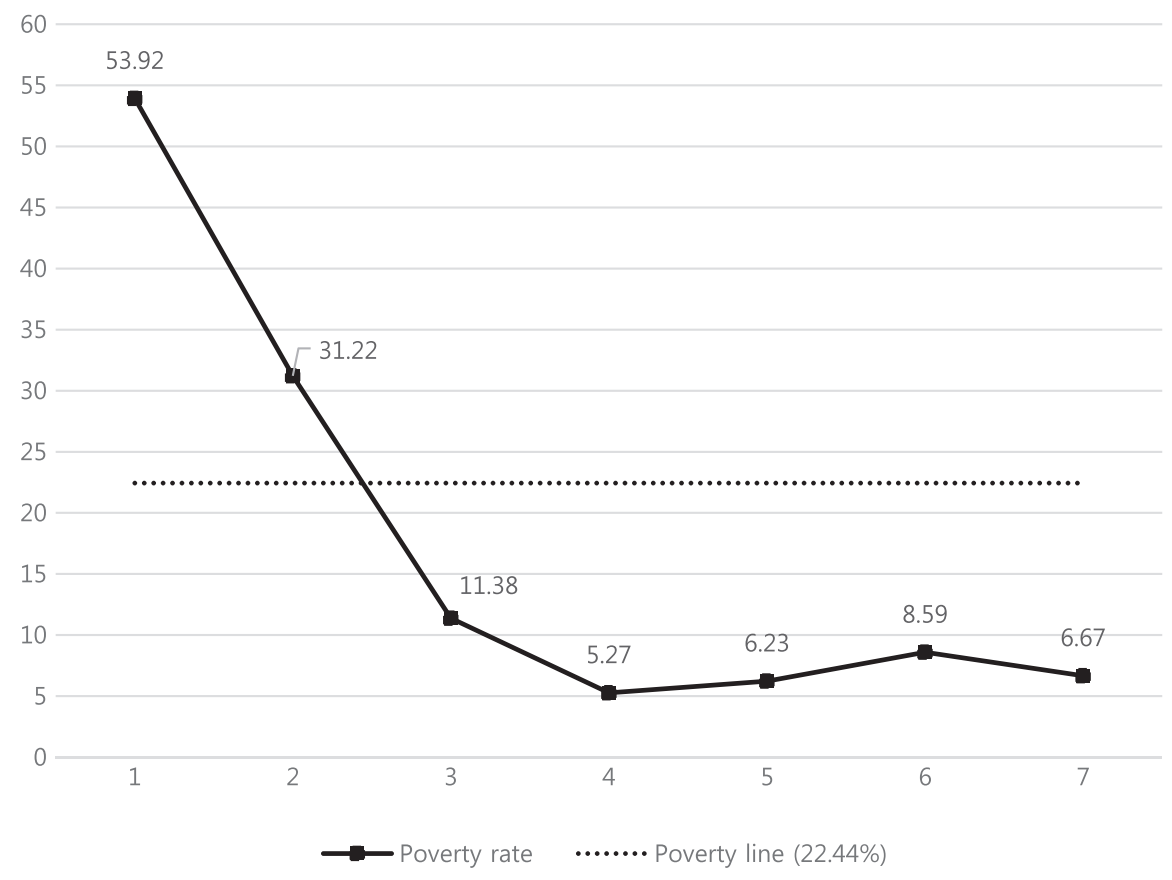

Figure 5: Household size and relative poverty rate in \%, 2015.

Source: Statistics Korea (2017).

\section{Growing gaps and inequality}

We discussed the three dimensions of socio-economic change that aggravated the income distribution of individuals and households in South Korea. These three aspects of socio-economic change interact to generate income inequality that we may experience in everyday life. As shown in Table 2, the Gini coefficients measuring household income, have remarkably increased since 1998. While the Gini coefficient in 1998 was 0.311, it continuously increased up to 4.01 in 2011. It stagnated between 2012 and 2014 but rebounded in 2015. The adjusted Gini coefficients are estimated, adjusting the low representatives of the rich in the household income and consumption survey. We might safely infer from Table 2 that the inequality of household income has been getting worse in the post-crisis period since 1997. The pace of deterioration of income distribution has been much faster in the 2000s. The Gini coefficient stagnated at a high level, yet showing an equilibrium of income inequality at the high level. 
Table 2: Gini coefficients and income share by the highest $10 \%, 1998-2015$.

\begin{tabular}{rrrrr}
\hline Year & $\begin{array}{r}\text { Adjusted } \\
\text { Gini }\end{array}$ & $\begin{array}{r}\text { Gini for all } \\
\text { households }\end{array}$ & $\begin{array}{r}\text { Gini for households with more } \\
\text { than one person }\end{array}$ & $\begin{array}{r}\text { Income share by the } \\
\text { highest 10 \% }\end{array}$ \\
\hline 1998 & 0.311 & & & 0.331 \\
1999 & 0.325 & & & 0.329 \\
2000 & 0.316 & & & 0.364 \\
2001 & 0.325 & & & 0.387 \\
2002 & 0.336 & & 0.292 & 0.377 \\
2003 & 0.339 & & 0.301 & 0.368 \\
2004 & 0.340 & & 0.306 & 0.403 \\
2005 & 0.363 & & 0.312 & 0.440 \\
2006 & 0.377 & 0.330 & 0.321 & 0.467 \\
2007 & 0.376 & 0.340 & 0.323 & 0.463 \\
2008 & 0.383 & 0.344 & 0.320 & 0.461 \\
2009 & 0.372 & 0.345 & 0.314 & 0.456 \\
2010 & 0.381 & 0.341 & 0.313 & 0.464 \\
2011 & 0.401 & 0.342 & 0.311 & 0.474 \\
2012 & 0.383 & 0.338 & 0.308 & 0.471 \\
2013 & 0.393 & 0.336 & 0.309 & 0.473 \\
2014 & 0.394 & 0.341 & 0.307 & 0.479 \\
2015 & 0.401 & 0.341 & & 0.485 \\
\hline
\end{tabular}

Source: Hong (2018: 17).

The above estimation of trends of Gini coefficients is based on the household income and consumption survey (HICS). The HICS analyzed here has not been comparable since the population sampled in the survey has changed over time. Until 2003, only urban households with more than or equal to two persons were included in the sample in urban areas. The HICS survey began to include all households including single households in rural areas from 2006. However, the HICS was criticized for not including enough high-income households, generating an underestimation of income inequality. ${ }^{21}$

Table 2 also reports the income share of the richest $10 \%$ in South Korea; it increased from 0.331 to 0.471 . This concentration of income in the highest income group has continued in the 2000s even after the economy had digested the 1997 crisis. The highest $10 \%$ income group shared almost half of the total income in 2015,

21 Hong 2018. In 2015, the proportion of the high-income group over 100,000,000 Won was $4.62 \%$ in the HICS data, whereas it is $8.68 \%$ in the household finance and welfare panel survey (HFWPS) data. The income distribution of South Korea has been reported by international institutions such as the OECD and World Bank, based on an analysis of the HICS data. This results in an underestimation the Gini coefficients of household income. 
and the lowest $10 \%$ of income share has been shrunk, generating a polarization of income. The three socio-economic changes - the increase of the working poor due to precarious employment, the growth of the elderly population without appropriate income, and the expansion of poor single households - have interacted to aggravate income distribution in South Korea.

Table 3 reports a decomposition of income inequality by factors, applying regression-based income decomposition. ${ }^{22}$ The household finance and welfare panel survey (HFWPS), collected in 2010 as a remedy of the HICS, was used for the regression-based inequality decomposition. The income-generating functions for a regression model contain factors associated with household income such as human capital, employment status, household structure, and aging. ${ }^{23}$ They do not directly show casual relations but reveal social dynamics of income inequality in South Korea.

Table 3 consists of two parts. One is income inequality among households with a working household head. One-fourth of the population does not work due to non-active labor forces, unemployment, or retirement. Income inequality among the households with employment comprises the largest proportion of the household. Another is income inequality among the entire household with both the working and non-working population. It is social inequality in that all social groups, including the elderly retired from work, are included in the measure of income inequality.

The first two columns of Table 3 report the contribution of each factor to household income inequality among households with a working household head. Education indicates the largest contribution (33.69\% or $29.51 \%$ ) to income inequality, while employment status or occupation is the second largest contributing factor $(27.01 \%$ or $28.84 \%$ ) to income inequality. Considering the fact that nine categories of occupation (manager, professionals, clerics, service workers, sales workers, farmers, skilled workers, operators, unskilled workers) are used and seven categories of employment status (regular employee, temporary or daily workers, self-employed without employees, self-employed with employees, family workers without wages, other atypical workers such as delivery service workers working on their own account, employment status is a more parsimonious factor than occupation in explaining income inequality. Employment status is not

22 Fields 2003; Shorrocks 1982, 1984.

23 The income function used in this analysis is as follows: $\log ($ income $)=\mathrm{a}+b i X i+\mathrm{e}$, where Xi includes sex ( 0 =male, 1 = female), age, age squared, education (years of schooling), employment status or occupation, the elderly $(0=1-64,1$ is equal to or over 65$)$, single household, marital status ( 1 =non-married, 2 = married, 3 = divorced, $4=$ spouse deceased), urban resident ( 0 = urban, 1 = non-urban). 
Table 3: Regression-based household income inequality decomposition among the employed, 2010.

\begin{tabular}{lrrrr}
\hline Variable & $\begin{array}{r}\text { Working } \\
\text { Household Head }\end{array}$ & $\begin{array}{r}\text { Working } \\
\text { Household Head }\end{array}$ & $\begin{array}{r}\text { All } \\
\text { Households }\end{array}$ & $\begin{array}{r}\text { All } \\
\text { Households }\end{array}$ \\
\hline Sex & 1.6830 & 2.4066 & 1.0517 & 1.5422 \\
Age & $(3.57)$ & $(5.26)$ & $(1.79)$ & $(2.27)$ \\
& 4.5809 & 4.8282 & 4.0919 & 4.1537 \\
Education & $(9.72)$ & $(10.55)$ & $(6.98)$ & $(7.19)$ \\
& 15.8828 & 13.5091 & 16.5445 & 15.3590 \\
Emp. Status & $(33.69)$ & $(29.51)$ & $(28.22)$ & $(26.57)$ \\
& 12.7313 & & 18.5845 & \\
Occupation & $(27.01)$ & & $(31.70)$ & \\
& & & 18.5305 \\
Single Household & & 13.1992 & & $(32.05)$ \\
& 3.3623 & $(28.84)$ & & 6.6402 \\
Marital Status & $(7.13)$ & $(7.88)$ & $(10.84)$ & $(11.49)$ \\
& 5.0424 & 5.3365 & 4.8888 & 5.0119 \\
Old Age & $(10.67)$ & $(11.66)$ & $(8.34)$ & $(8.67)$ \\
& 3.2355 & 3.1094 & 6.3526 & 6.1720 \\
Residential Area & $(6.86)$ & $(6.79)$ & $(10.84)$ & $(10.68)$ \\
& 0.6218 & 0.4724 & 0.5938 & 0.8885 \\
Total & $(1.32)$ & $(1.03)$ & $(1.01)$ & $(1.54)$ \\
& 47.139 & 45.7708 & 58.6200 & 57.8100 \\
& $(100.00)$ & $(100.00)$ & $(100.00)$ & $(100.00)$ \\
\hline
\end{tabular}

Note: Estimates of the impact of each variable are based on the following regression model in which the dependent variable is a logarithm of household income and independent variables are sex, age, years of education, employment status, occupation, old age, family type, and residential area.

equivalent to social class; it captures class cleavages between business owners and business non-owners and between regular workers and non-regular workers. The correlation between occupation and employment status is so strong that the net improvement of explanatory power by including both factors to the model is trivial. In short, it must be reasonable to argue that almost one-third of income inequality among households with a working household head is due to work. Household factors including single households and marital status (unmarried, married, divorced, and deceased) of household head explain almost $18 \%$ of income inequality among households with a working household head. The old age dummy variable also contributes to income inequality substantially with $6-7 \%$ of income inequality. 
The last two columns of Table 3 show the contribution of each factor to income inequality among all households including both households with working household head and households with non-working household head. Thus, the elderly population without work is included in the analysis. Working status measured by employment status increases its impact on income inequality from $27.01 \%$ to $31.70 \%$ and working status by occupation also increases its impact from $28.84 \%$ to $32.05 \%$. Since non-working households are included in the analysis, the contribution of both to income inequality is larger. Demographic factors contribute to income inequality by $8.77 \%$ or $9.46 \%$, while education contributes by $28.22 \%$ or $26.57 \%$. However, the impact of education on income inequality reduces by almost 3-5\% with an expansion of the population.

It also should be mentioned that the explanatory power of the regression models has substantially improved by enlarging the social group from households with household heads working to all households. The income inequality among households with a working household head is directly related to labor market inequalities, whereas income inequality of all households in society includes households of retired and unemployed people. Household factors' contribution to income inequality increases by almost $2 \%$ with the inclusion of the non-working population whereas contribution by demographic factors to income inequality decreases by $4-6 \%$. The elderly, a binary categorical variable differentiating household heads aged over 65 from those below 65, displays a substantial increase in its contribution to income inequality by almost $4 \%$.

Table 4 shows the result of a regression-based decomposition of inequality in 2016. The general pattern of the relationship between income inequality and factors is almost the same as that in 2010. Economic factors such as employment status or occupation substantially affect income inequality. Nevertheless, we observe some noticeable changes, one of which is the rising contribution of the single household to the overall income inequality between 2010 and 2016. Household type explains $16 \%$ of the total inequality of income; it increased from $10-11 \%$ in 2010 to $16 \%$ in 2016. This indicates that the rising importance of the single household has become an important source of rising inequality. The impact of age on income inequality has also increased, revealing the fact that age has been working as an important source of income inequality in South Korea. Also, the extent to which education plays a role in shaping income inequality has been diminishing from 2010 to 2016. The diminishing effect of education on income inequality seems to reflect a new social change in South Korea. While educational competition has become tougher than ever before, the role of education in making income gains seems to be getting weaker. 
Table 4: Regression-based household income inequality decomposition among the employed, 2016.

\begin{tabular}{lrrrr}
\hline Variable & $\begin{array}{r}\text { Working } \\
\text { Household Head }\end{array}$ & $\begin{array}{r}\text { Working } \\
\text { Household Head }\end{array}$ & $\begin{array}{r}\text { All } \\
\text { Households }\end{array}$ & $\begin{array}{r}\text { All } \\
\text { Households }\end{array}$ \\
\hline Sex & 3.2527 & 4.0386 & 2.8674 & 3.4277 \\
Age & $(6.72)$ & $(8.53)$ & $(4.62)$ & $(5.57)$ \\
& 5.6424 & 6.0117 & 4.4093 & 4.9178 \\
Education & $(11.65)$ & $(12.70)$ & $(6.62)$ & $(8.00)$ \\
& 12.1486 & 10.2709 & 14.7549 & 13.5297 \\
Emp. Status & $(33.69)$ & $(21.70)$ & $(23.78)$ & $(22.00)$ \\
& 11.5117 & & 19.6973 & \\
Occupation & $(25.09)$ & & $(31.74)$ & \\
& & & & 19.2151 \\
Single Household & & 10.7322 & $(31.24)$ \\
& 6.5528 & 6.4544 & 9.9463 & 9.8578 \\
Marital Status & $(13.53)$ & $(13.64)$ & $(16.03)$ & $(16.03)$ \\
& 6.6953 & 7.7790 & 4.2970 & 4.6463 \\
Old Age & $(13.83)$ & $(16.44)$ & $(6.93)$ & $(7.56)$ \\
& 2.3530 & 2.3364 & 5.7484 & 5.6247 \\
Residential Area & $(4.86)$ & $(4.94)$ & $(9.26)$ & $(9.15)$ \\
& 0.2603 & 0.2022 & 0.3246 & 0.2801 \\
Total & $(0.54)$ & $(0.43)$ & $(0.50)$ & $(0.46)$ \\
& 48.4200 & 47.3300 & 62.0500 & 61.5000 \\
& $(100.00)$ & $(100.00)$ & $(100.00)$ & $(100.00)$ \\
\hline
\end{tabular}

Note: Estimates of the impact of each variable are based on the following regression model in which the dependent variable is a logarithm of household income and the independent variables are sex, age, years of education, employment status, occupation, old age, family type, and residential area.

\section{Conclusion}

In this paper, we attempted to explore the causes of rising income inequality in the post-crisis period in South Korea after 1997. This increasing inequality has been observed for the last three decades in South Korea. Income inequality measured by the Gini coefficient and the concentration of income by the highest $10 \%$ income group shows that the level of inequality in South Korea is much higher than most other OECD members in the 2000s. Furthermore, at the same time, the rise in the poverty rate also shows that the worsening income distribution is not temporary but a 'new normal' in the 2000s. 
The financial crisis in 1997 became a watershed of social transformation conducive to a deteriorating income distribution. Radical neo-liberal reforms by the state, such as deregulation of the labor market, has generated massive precarious workers and non-regular workers among others. Although the financial crisis in 2008 did not hamper the Korean economy as it did in other OECD countries, it hampered the recovery of the labor market already damaged by the 1997 financial crisis. Now, the rise of precarious employment seems to be an irreversible trend in the labor market in Korea.

In addition, population changes, such as rapid aging and rising single household and a family crisis partly associated with the financial crisis, have exacerbated the deterioration of income distribution further. The rapidly aging population has contributed to the increasing proportion of the elderly poor. The rise of single households also increased the rise of the poor, as it was associated with an increasing divorce rate and the rising elderly poor. The combination of these factors has contributed to the trend of rising income inequality in the 2000s.

Discourses on "social polarization" began to dominate the political debates during the 2012 Presidential election. Both liberal parties and conservative parties attempted to provide diagnoses and policy measures to reduce economic inequality. Now economic inequality has become a touchstone of the performance of each government by media and academics. While economic growth was the core of policy discourse in the past, now how to tackle economic inequality has become the core criterion for evaluating the performance of the government.

However, the state has limitations in reducing inequality immediately since there are many factors beyond the boundaries of direct policy intervention and the effect of policy intervention needs time to materialize. Divorces between couples and wage determination by private enterprises may be out of a state's policy, whereas raising the minimum wage and state welfare programs might be the best policy areas where the state could directly intervene with policy measures. Welfare programs for single households could be implemented by an introduction of a new delivery system of welfare services. The tax system has been considered as the most direct policy measure to change income distribution in the industrial society.

Korea needs more comprehensive policy measures to halt rising inequality. Because of multiple sources of income inequality, the Korean government should provide adequate measures to get rid of poverty and lessen the level of income inequality. While the effect of state policies might need longer to materialize, a systematic approach to reducing income inequality should be required immediately. The Moon Jae-in government already increased the 
minimum wage by $16.4 \%$ to lower the poverty rate among precarious workers and significantly raised the elderly pension to mitigate elderly poverty. However, social welfare programs related to poor children should also be thoroughly put into action to guarantee their education and training and prevent chronic adversity for the poor throughout their lifetime.

\section{References}

Amsden, Alice H. (1989): Asia's Next Giant: South Korea and Late Industrialization. Oxford: Oxford University Press.

Baliño, Thomás J. T. / Ubide, Angel (1999): “The Korean Financial Crisis of 1997: A Strategy of Financial Sector Reform”. IMF Working Paper WP/99/28. Washington: IMF (International Monetary Fund).

Chibber, Vivek (2014): “The Developmental State in Retrospect and Prospect: Lessons from India and South Korea". In: The End of Developmental State? Edited by Michelle Williams. New York: Routledge, 30-54. https://www.taylorfrancis.com/books/e/9781134656974.

Chung, Ee-Hwan (2002): "Inequality in the Labor Market and Inequality within Organizations: A Study of Wage Inequality in the 1990s in Korea". Journal of Korean Sociology 36.6: 1-25.

Chung, Ee-Hwan (2007): "Wage Inequality in Korea from a Comparative Perspective”. Journal of Korean Sociology 49.4: 65-100.

Chung, Kyung-Hee / Nam, Sangho / Chung, Eunji / Lee, Jihye / Lee, Young-Kyung / Kim, Jungseok / Kim, Haeyoung / Jin, Mee-jung (2012): Policy Implications of Changes in Family Structure: Focused on the Increase of Single Person Households in Korea. Sejong: Korea Institute for Health and Social Affairs.

Dao, Mai / Furceri, Davide / Hwang, Jisoo / Kim, Meyeong / Kim, Tae-Jeong (2014): "Strategies for Reforming Korean's Labor Market to Foster Growth”, IMF Working Paper WP/14/137. Washington: IMF (International Monetary Fund).

Fields, Gary S. (2003): “Accounting for Income Inequality and Its Change: A New Method, with Application to the Distribution of Earnings in the United States". In: Worker Well-Being and Public Policy (Research in Labor Economics, Volume 22). Edited by Solomon W. Polachek. Bingley: Emerald, 1-38.

Hong, Minki (2018): “Correcting Gini Coefficients in Korea”. The Journal of Economic Development.

Kim, Hincheon (2010): "Business Groups in South Korea”. In: The Oxford Handbook of Business Groups. Edited by Asli M. Coplan, Takashi Hikino, James R. Lincoln. Oxford: Oxford University Press, 157-179.

Kim, Seung-kyung / Finch, John (2002): “Confucianism Patriarchy Reexamined: Korean Families and the IMF Economic Crisis". The Good Society 11.3: 43-49.

KLI (Korea Labor Institute) (2016): 2016 Poverty Statistics. Seoul: KLI.

KLI (Korea Labor Institute) (2017): KLI Labor Statistics. Seoul: KLI.

Lee, Jaehyung (2014): "Business Groups in Korea: Overall Concentration, Market Dominance and Diversification”. KDI Policy Forum 262: 1-10.

Nam, Duck-Woo, Kong-Kyun, Ro (1981): "Population Research and Population Policy in Korea in the 1970s". Population and Development Review 7.4: 651-669. 
OECD (Organisation for Economic Co-ordination and Development) (2016): OECD Factbook 2015-2016. Paris: OECD.

OECD (Organisation for Economic Co-ordination and Development) (2017): Education at a Glance: Indicators. Paris: OECD.

Park, Insook Han / Cho, Lee-Jay (1995): “Confucianism and the Korean Family". Journal of Comparative Family Studies 26.1: 117-134.

Shorrocks, F. Anthony (1982): “Inequality Decomposition by Factor Components". Econometrica 50.1: 193-211.

Shorrocks, F. Anthony (1984): “Inequality Decomposition by Population Sub-Groups". Econometrica 52.6: 1369-1385.

Statistics Korea (2015): 2015 Social Indicators. Statistics Korea: Sejong.

Statistics Korea (2017): 2017 Social Indicators. Statistics Korea: Sejong.

Williamson, John (1990): “What Washington Means by Policy Reform”. In: Latin American Readjustment: How Much Has Happened. Edited by John Williamson. Washington: Institute for International Economics, 7-20. 